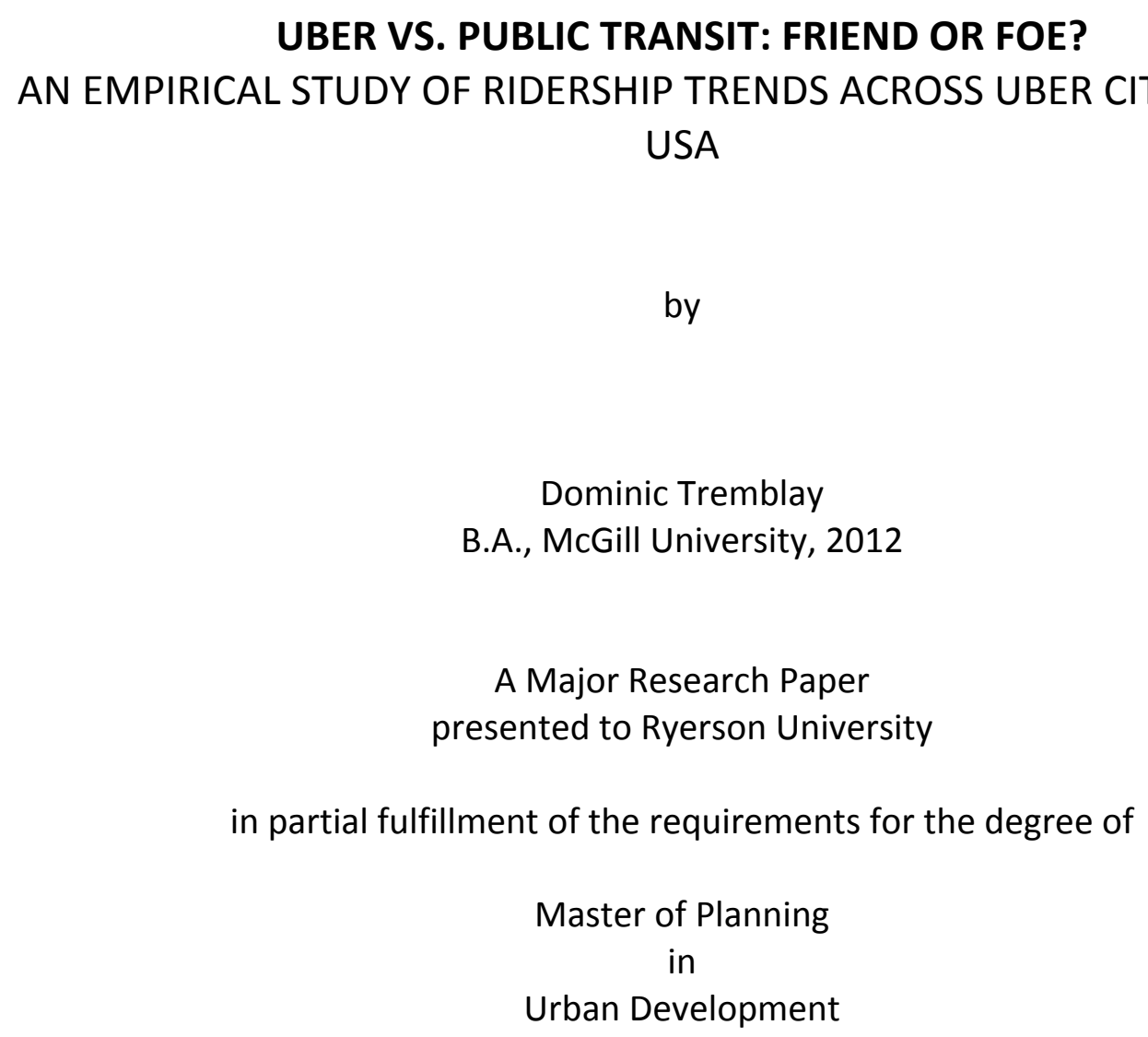

Toronto, Ontario, Canada, 2016

CDominic Tremblay 2016 


\section{Author's Declaration for Electronic Submission of a MRP}

I hereby declare that I am the sole author of this MRP. This is a true copy of the MRP, including any required final revisions.

I authorize Ryerson University to lend this MRP to other institutions or individuals for the purpose of scholarly research.

I further authorize Ryerson University to reproduce this MRP by photocopying or by other means, in total or in part, at the request of other institutions or individuals for the purpose of scholarly research.

I understand that my MRP may be made electronically available to the public. 


\title{
UBER VS. PUBLIC TRANSIT: FRIEND OR FOE? AN EMPIRICAL STUDY OF RIDERSHIP TRENDS ACROSS UBER CITIES IN THE USA
}

\author{
(C)Dominic Tremblay, 2016 \\ Master of Planning \\ in \\ Urban Development \\ Ryerson University
}

\begin{abstract}
Uber is a disruptive transportation network company (TNC) that is affecting the way people move in cities. While its effects on the taxi industry are increasingly clear, little research has been conducted to study its effects on public transit ridership. This study uses descriptive statistics to establish demographic and socio-economic profiles of cities that Uber has targeted, and a quasi difference-in-difference analysis to explore Uber's effect on transit ridership levels in order to determine whether the service is acting as a complement or substitute to public transit. The results from this high-level study suggest that Uber may be more of a complement to transit over time, and in large, dense regions with highly-educated, affluent, productive labour markets that already have very high transit ridership. Finally, recommendations informed by these findings are offered for transit agencies, policy makers, and municipal governments as they continue to determine how to regulate Uber and similar ridesourcing services.
\end{abstract}

Key Words: Uber; Public Transit; USA; TNC; Regulation 


\section{Acknowledgments}

The successful completion of this paper would not have been possible without the concerted efforts of a highly generous, intelligent, and thoughtful supporting cast.

My thanks first go out to my supervisor Dr. Matthias Sweet for sharpening a rough initial idea for this paper into a well-structured and meaningful study, and for being so generous with your time, dedication and intellectual processing power from start to finish.

Thank you to Dr. Murtaza Haider for offering your time and providing thorough subject matter expertise as my second reader.

I must also acknowledge the continued support of the SURP faculty and administration throughout my time in the M.PI program, and in particular Julia Macan for your endless positivity and energy.

Un gros merci and thank you to my loving family who have always supported and encouraged me in everything that I do.

Gordana, thank you for your love of me and of data, and for always motivating me to take on greater challenges.

And finally to my friends and classmates who are celebrating their degree alongside me: thank you for two lightning-fast years of intellectual stimulation and friendship, filled with memories of neighbourhood explorations, unexplainable laughter, trivia, healthy salad lunches, unhealthier dinners, contact, dice, and endless cheers-ing. I will miss our uniquely tight-knit and talented graduate student community. 


\section{Table of Contents}

List of Figures ..................................................................................................... p. vi

Chapter 1: Introduction............................................................................ p. 1

1.1 Purpose of this paper ...................................................................... p. 1

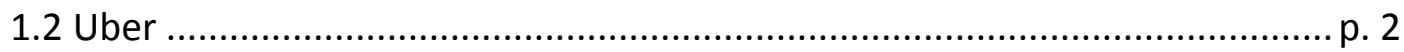

1.3 Literature review............................................................................... p. 7

1.4 Research gap ....................................................................................... 11

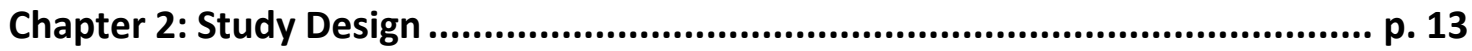

2.1 Research Hypotheses ....................................................................... p. 13

2.2 Data Collection .................................................................................. 14

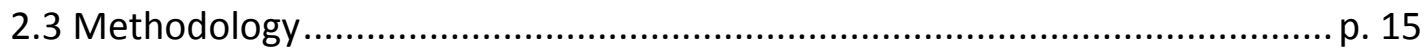

Chapter 3: Results .................................................................................. p. 19

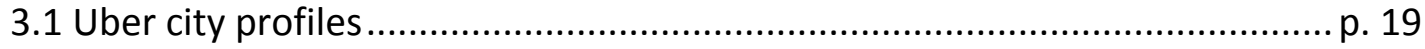

3.2 Effects on transit ridership .............................................................. 27

Chapter 4: Conclusions and Recommendations ......................................... p. 31

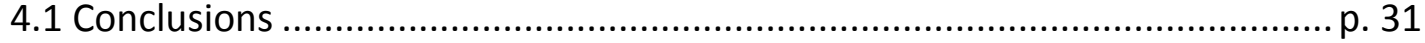

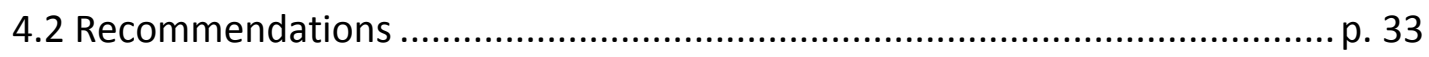

4.3 Study limitations and direction for future research .................................. p. 34

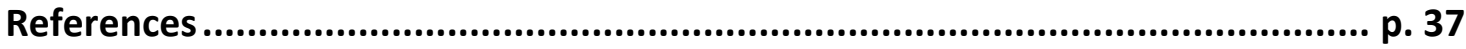




\section{List of Figures}

Figure 1: Mode preference by time of day and week .................................... p. 9

Figure 2: Trip purpose for recent users of ridesourcing .................................. p. 9

Figure 3: All Uber UZAs by year of Uber entry, i.e. Uber city groups ..................... p. 19-20

Figure 4: Uber City Groups by median household income ................................ p. 21

Figure 5: Uber City Groups by population density ......................................... p. 22

Figure 6: Uber City Groups by percentage of bachelor degree or higher ............... p. 23

Figure 7: Uber City Groups by median age ...................................................... p. 24

Figure 8: Uber City Groups by rates of car ownership .................................... p. 25

Figure 9: Uber City Groups by percentage of working population by industry....... p. 26

Figure 10: Current day transit ridership levels across Uber and non-Uber cities.... p. 27

Figure 11: Transit ridership of Uber City Groups over a 10-year period ................ p. 28

Figure 12: Ridership growth of Uber cities compared to No Uber cities................ p. 29 


\section{CHAPTER 1: Introduction}

\subsection{Purpose of this paper}

Technologies affect mobility. Throughout history, various innovations in transportation technology have had a significant influence on how people travel, where they choose to live, and the lifestyle they can afford to have. However, integrating emerging new technologies into existing transportation systems can be a painful process for users and operators. Whenever such technological changes occur, older technologies often lose out to the new. In today's increasingly connected world in which, by 2020, 70 percent of the world's population will be using a smartphone, and $90 \%$ of it will be covered by mobile broadband networks (Ericsson, 2015), technology appears to be on the verge of significantly affecting people's mobility once more.

Uber is a transportation network company (TNC) that has capitalized on increased global connectivity. Since its debut in 2010 , the company's political tactics and smartphoneenabled ridesourcing technology have made it a highly disruptive force in the urban transportation landscape. Most indications suggest that the taxi industry is being strongly impacted by TNCs, as reflected by the industry's vigorous and sometimes violent opposition to Uber's entrance into new markets. As governments across the world determine how to integrate this disruptive new technology into their existing transportation networks alongside taxis, concerns have been raised about how this technology is affecting public transit systems (Wadhwa, 2014).

How will Uber impact public transit use? This is an important question for cities, because Uber and other TNCs have the potential of disrupting public transit service provision by eating into its market share, and therefore negatively affecting the mobility of residents who primarily rely on transit. Indeed, Uber's effect could be significant enough to force a transit agency to reduce its service due to a loss of ridership and revenues. As a consequence, the mobility of residents once ensured by a public service would be left in the hands of a private entity only guided by the profit motive. The 
vulnerable ridership in this case could therefore be much worse off over time. For this scenario to be a legitimate concern, however, Uber would have to be demonstrably taking ridership away from public transit. Has this been the case?

This research paper attempts to answer this question by examining the relationship between public transit ridership and the emergence of Uber in cities across the United States. By looking at descriptive statistics of ridership trends, the primary goal of this research is to determine at a high level what effect Uber is having on transit ridership, and to determine if it is acting as a complement or substitute. Secondary goals of the research are to establish a profile of cities where Uber has entered the market, in order to understand why the arrival of the company in a given city may have had a more significant effect in transit ridership, and attempt to determine through empirical evidence if Uber views itself as a complement or substitute to public transit. Finally, this paper offers recommendations based on this research for transit planning agencies, municipal governments, and policy makers across North America as they continue to adapt to a changing transportation landscape as a result of new technologies.

\subsection{Uber}

\section{What is Uber?}

Uber is a multinational TNC that launched in 2010. It operates in more than 300 cities in over 60 countries worldwide, relies on a network of over one million private drivers globally (Uber, 2016), and is currently valued at more than $\$ 50$ billion (USD) according to Fortune magazine (Gandel, 2015). This so-called "disruptive" technology company is currently worth more than other notable disruptive firms of the $21^{\text {st }}$ century such as Tesla Motors (\$29 billion) (Angelo, 2015), SpaceX (\$12 billion) (D’Onfro, 2015), and Airbnb (\$26 billion) (Alba, 2015). Uber’s success is largely attributable to the rapid rise in popularity of its smartphone application in which users can request a car trip from an Uber driver who will, through a similar GPSenabled Uber application interface on their smartphone, be given pick-up location and destination information prior to the user's entry into the personally owned vehicle. The cost 
of a trip is based on its distance, number of riders in the car, and an algorithm that calculates area-wide demand for the service called "surge pricing" (Uber, 2016). Payment for service is also pre-arranged through the application.

The company offers several variations on this smartphone-based service model, ranging from UberPool in which users with similar locations and destinations are grouped in the same Uber vehicle, UberHop in which Uber vehicles drive along fixed routes during commuting times, to even more localized Uber services such as UberSki in Salt Lake City that offers direct rides to ski slopes (Uber, 2016). Various new Uber concepts are routinely developed and piloted in cities across the world.

While Uber does have competitors in an emerging transportation network company market in North America- Lyft, Sidecar, and others offer similar services- Uber is currently the largest player. It has also received the most significant media coverage and governmental attention. Uber was therefore chosen as the TNC of study in this paper because it was the one most likely to have had an effect on transit ridership to date given its scale of operations, and because its success to date may provide insight as to which cities are best suited or vulnerable to TNCs.

\section{Possibilities for cities and planning implications}

Uber purports to act in a city's best interests in several ways: by creating jobs and additional income sources for its drivers, by acting as a complement to transit by bringing people to and from transit stations and hence providing a solution to the first/last mile problem, by reducing drunk driving, and by reducing the total number of cars on the road through use of its UberPool service in particular (Uber, 2016). More broadly, Uber and similar ridesourcing TNCs have the potential to positively address certain environmental, economic, and social issues.

Environmentally, TNCs such as Uber can have positive effects in cities by potentially: 
- Providing a service that reduces the need to purchase and own a private automobile (Taylor et al. 2016, 30)

- Catalyzing the development of zero-emissions and autonomous vehicles through increased collaboration between technologically-inclined companies

- Reducing physical cash transactions often required by traditional taxicab services

According to Silverstein (2014), Uber may enable more alternate choices to car ownership, as Uber is generally less costly than taxis but offers a similar service. Environmental benefits from Uber may or may not materialize, depending on regulatory context, as Uber may incur no net environmental benefit if it offsets current sustainable options or increases travel demand (Velickovic, 2015). Nevertheless, the benefits of TNCs are potentially significant, and through collective regulatory action could be harnessed to bring about positive environmental effects. As an example of how technologies can catalyze environmental gains, with the rise of UberPool, Uber has developed a system to get two or more potential drivers into one vehicle. Moreover, given that Uber predicts it will rely on driverless cars in the future (Gilbert, 2015), which are expected to be electric (Mui, 2016), Uber may catalyze environmentally sensitive mobility.

Uber also appears to leverage environmental sensibility as a tool for growing its business. On Earth Day in 2015, Uber came out with a variety of city-specific promotions like discounts on its carpool service in New York, and the ability to request hybrid or electric vehicles in Boston. In Seattle, Uber partnered with local bus and bike share services to host a "Ditch Your Keys Challenge" (Cohen, 2015).

Economically, TNCs may generate positive effects at governmental, agency and individual scales by potentially: 
- Providing a new source of municipal revenue through fees or taxes (Taylor et al. 2016, 54)

- Filling gaps in transportation network coverage (Donahue, 2015) caused by limited funding of public transit agencies

- Coordinating with public transit agencies to deliver private sector-led technologies that lead to more efficient service delivery

- Providing more affordable and a wider variety of choice in mobility compared to individual car ownership that gives access to greater economic opportunities (Taylor et al. 2016, 67)

Examples of potential cost savings on the transit supply side can come in the form of measures such as dynamic pricing and seamless smartphone user interface across different modes. Certain transit agencies in the USA have already experimented with this type of collaboration. In Dallas, a pilot program was set up for St. Patrick's day in 2015 where DART (Dallas Area Rapid Transit) customers were offered free Uber rides to/from the transit station to their starting and ending destinations (DART, 2015). Following the success of this program, the transit agency and the private company have since joined forces by offering the Uber app as part of the transit system's suite of mobile platform services. This is a first step toward integrating Uber as part of the transit network's standard offerings of buses and light rail, though Uber still operates as a separate financial entity. Similarly in Atlanta, MARTA (Metropolitan Atlanta Rapid Transit Authority) customers are able to use the Uber mobile platform to pay for their transit fee, and cover their "first/last mile" trip using an Uber car. This is part of the transit operator's bid to modernize its mobile platform, while providing its users with a greater amount of mobility options (Simmonds, 2015).

In terms of social issues, TNCs like Uber can have positive effects by potentially increasing the urban mobility of residents lacking the means to afford private car ownership (Taylor et al. 2016, 138). By providing these residents with an affordable 
option to make non-routine trips that require a car, Uber and similar TNCs could potentially be meeting broader social needs currently unmet by public transit agencies.

\section{Regulatory battles}

Despite these potential positive impacts brought on by TNCs, the legality and questions surrounding regulation of TNCs like Uber have sparked fierce debates and various responses around the world. In most cases, the main complainant against Uber has been the taxi industry. Generally, taxi agencies argue that Uber is unfairly taking away from their business by circumventing the municipal regulations by which they are forced to abide. In response to these reactions and their city's transportation needs, municipal governments have taken varying measures to curb this anger, ranging all the way from enforced citywide bans, to subsidizing Uber trips to and from transit stops for residents in suburban communities (Liston, 2016).

\section{Uber and public transit}

While most of the controversy surrounding Uber has been centered around its impact on the taxi industry, its possible impact on public transit has received less attention. Uber describes itself as a complement to transit- in San Diego, Uber claims that its platform "allows safe and reliable rides to happen at all hours of the day, supporting and extending San Diego's public transportation system." To achieve this, Uber admits that "gaps in public transportation become hubs for Uber" and that they go where bus and rail do not, while also "making it easy for people to take advantage of the existing public infrastructure" (Donahue, 2015).

If this is indeed the case, are there specific conditions under which Uber acts as a complement or a substitute? Does Uber encourage the use of public transit by way of promoting a car-free lifestyle in which trips previously made by a personal vehicle are now replaced by transit, and non-routine auto trips are replaced by Uber? Or 
alternatively, has Uber been taking away from transit ridership by offering a faster, more reliable service for commuting?

In order to begin answering these questions and effectively understand how Uber affects public transit use, a broader exploration of Uber's recent impact on transportation is required.

\subsection{Literature Review}

Given Uber's relative novelty, its ongoing expansion, and its rapidly evolving suite of services, transportation planning literature is still just starting to understand the implications of Uber and TNCS on transportation systems and how to plan for them. Relatively little research has empirically tested the links between Uber services and public transit use.

\section{Uber-specific studies}

Haider et al. (2015) examine the effects of possible taxi service deregulation as a result of the emergence of TNCs, by documenting existing research on the relationship between taxicab deregulation, fleet sizes, and congestion and tailpipe emission increases in New York City. The authors conclude that deregulation of the taxicab industry would lead to more cars on the road, leading to higher traffic congestion and increased tailpipe emissions, and that the City of Toronto should consider these findings in their recommendations on how to regulate Uber. Notably, the study points to a poll conducted in Toronto in September 2015 that suggests that ridesharing services such as Uber are taking riders away from transit (CNW, 2015). In this poll, 1 out of 4 respondents who use both Uber and public transit expected their usage of transit to decrease because of Uber.

Rayle et al. (2014) examine the question of how ridesourcing services and taxis compare according to trip types, customers, and locations served. They also examine if 
ridesourcing complements or competes with public transit, and they look at its potential impacts on passenger miles traveled. The results of their intercept survey in San Francisco notably revealed that ridesourcing serves a "previously unmet" demand for convenient "point-to-point" travel typically shorter than the average taxi ride; that users of ridesourcing tend to be younger and own fewer cars; that ridesourcing appears to substitute transit on longer trips but otherwise complements transit; and that there is an unclear relationship between private automobile use and ridesourcing. But whereas the poll referenced in the Haider et al. (2015) study suggests that Uber may substitute for public transit trips, Rayle et al. (2014) provide evidence that Uber may be inducing demand for new trip types, and not substituting for any other mode.

In a study published by the American Public Transit Association titled "Shared Mobility and the Transformation of Public Transit", Murphy et al. (2016) use a mixed method approach to examine the relationship between public transportation and shared modes- referring in this study to bikesharing, carsharing, and ridesourcing. Through indepth interviews with transportation officials, a survey of 4,500 shared mobility users, and an analysis of transit and ridesourcing capacity and demand, the authors notably determined that the more people use shared modes, the more likely they are to use public transit, own fewer cars, and spend less on transportation overall, and that shared modes complement public transit, enhancing urban mobility (Murphy et al., 2016). These findings are broadly consistent with those of Rayle et al. (2014).

Moreover, it was determined that ridesourcing services are most frequently used for social trips between $10 \mathrm{pm}$ and $4 \mathrm{am}$, at times when public transit runs infrequently or is not available, that shared modes substitute more for automobile trips than public transit trips, and that people don't commonly use ridesourcing for commuting. These findings suggest that users of ridesourcing do so situationally, and not regularly. The two figures below illustrate some of these findings: 
Figure 1: Mode preference by time of day and week*

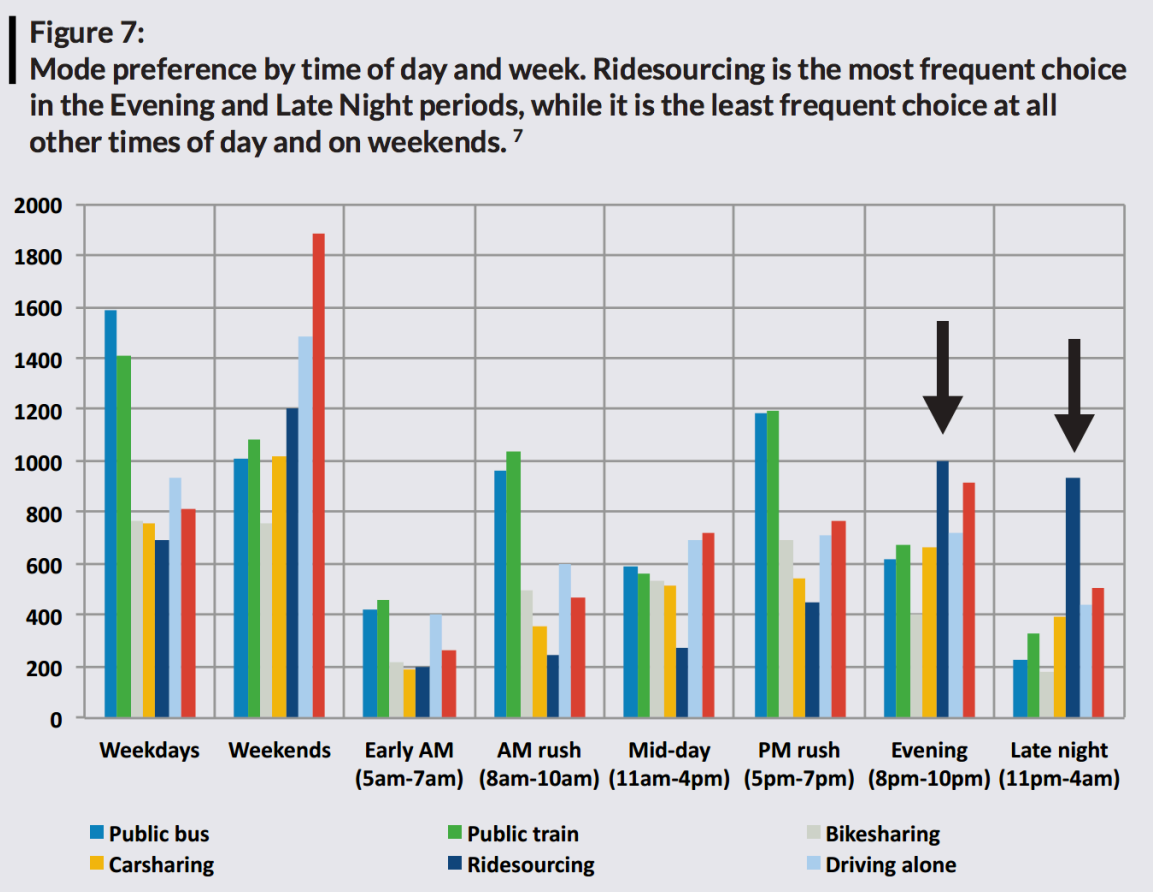

*Taken from Murphy et al. (2016), p.12

Figure 2: Trip purpose for recent users of ridesourcing*

Figure 6:

Recent use of ridesourcing, by trip purpose ${ }^{6}$

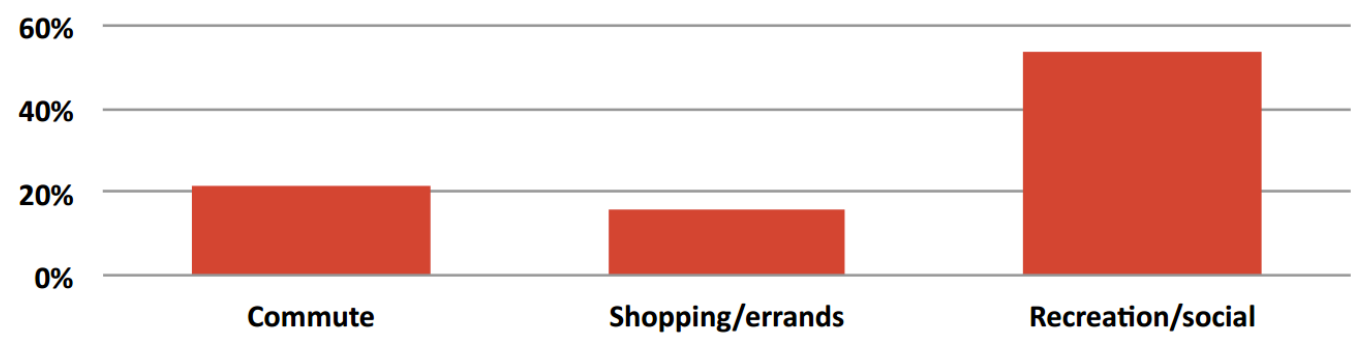

*Taken from Murphy et al. (2016), p.11

These two graphs suggest that users of ridesourcing do not use services like Uber most often for regular commuting purposes, but more often for less frequent, late-night social trips. The study ultimately recommends that public transit agencies can improve urban mobility of all its users by integrating new technology through collaboration with the private sector, in order to improve user experience and even paratransit service. It 
also points to the benefits of ridesourcing for low income residents, and underscores the role ridesharing and ridesourcing can play in helping people access destinations more easily reachable by car, while avoiding the costs of full-time car ownership.

While this extensive study that employed mixed methods presents very interesting findings, the cities in which the survey for the Murphy et al. (2016) study was put out were limited to Austin, Boston, Chicago, Los Angeles, San Francisco, Seattle, and Washington D.C.- cities that have relatively mature public transit systems. Chapter 3 will attempt to corroborate the findings of the Murphy et al. (2016) study through empirical evidence based on public transit ridership across a broader range in characteristics of urbanized areas, and determine if there are differences in cities where the transit system is less developed.

\section{Ridesharing}

As research on Uber, TNCs, and ridesourcing is nascent, lessons on Uber's potential implications can be gleaned by borrowing from related research, such as that on ridesharing. Martin \& Shaheen (2011) conducted an online survey of North American carsharing members of the carsharing industry's leading services (such as ZipCar, etc.). Their results showed that carsharing lowers the total number of vehicles owned by carsharing service members, and that carsharing also deterred carless households from acquiring a new vehicle. Households joining carsharing owned an average of 0.47 vehicles per household before joining a carsharing service, but that average was shown to drop to 0.24 after membership. Indeed, carsharing households exhibited a dramatic shift towards a car-less lifestyle. While the Martin \& Shaheen (2011) study looks at a service that is not the same as a ridesourcing service such as Uber, it does demonstrate that providing people more access to cars that are not their own reduces rates of private car ownership and may encourage increased transit use. 
The literature reviewed in this section helps establish a theoretical foundation from which to derive hypotheses regarding the effect of Uber on public transit ridership. This foundation can be summed by the following statements:

- Uber may be inducing demand for new trip types, i.e. it is not eating into the market share of other transportation services.

- Use of ridesourcing services like Uber is more situational than regular.

- If people are given a reliable option to use a car that is not their own, they are more likely to forego car ownership.

\subsection{Research gap}

In providing this foundation, the parts of the literature reviewed also present interesting research gaps in terms of methodology and scope when it comes to Uber. It is far from clear whether Uber is likely to complement public transit over the long-term as a mobility-housing bundle (i.e. the combined decision of where to live and how to travel) or whether it is likely to substitute for public transit and erode its market share. Different studies have found competing evidence - partly as a consequence of research design. Aside from the Murphy et al. (2016) study that approximated Uber demand data compared to transit, the other Uber studies that look at how it relates with public transit have used a survey approach, with varying conclusions. The poll mentioned in the Haider et al. (2015) study suggests that about one third of users expect their transit usage to decrease as a result of Uber, but does not specify which type of transit trips are expected to be substituted. The survey in Rayle et al. (2014) suggests that Uber perhaps complements transit for shorter trips. The Murphy et al. (2016) study shows that Uber use is more situational rather than commonplace.

An empirical look at ridership trends is warranted to further explore the conclusions drawn from these studies and to inform future research on the topic. Since Uber has been around in certain cities for over 5 years as of writing of this paper, it may be 
possible to observe some short and medium term effects of Uber on overall public transit ridership levels in cities where it has entered the market. Despite regulatory battles over Uber and other TNCs in North America and worldwide, decisions regarding regulating and planning for Uber will also benefit from baseline data to understand its effects on transit. In what types of cities is Uber making the most impact, and what is the nature of that impact? What if Uber could encourage the use of a government-run transit agency? The following chapter presents hypotheses informed by the background information and literature reviewed in this chapter, and describes the data and methods used to set up a study designed to explore these questions. 


\section{Chapter 2: Study Design}

\subsection{Research Hypotheses}

\section{Uber city profiles}

In order to contextualize ridership trends in cities across the USA in which Uber has entered ('Uber cities') and address the question of what type of cities Uber has prioritized and continues to target, it is useful to develop an understanding of these cities based on factors such as income levels, age, population density, and rates of car ownership. It might be expected that Uber prefers cities with higher population and population density, in which there are enough destinations to induce demand for new trip types not currently served by transit or other transportation services. Since large, dense cities typically have more robust transit networks, it is therefore expected that the cities that Uber prefers and targets initially will also be cities with greater transit use overall. However, if Uber's goal is to target cities that have insufficient transit to supply demand for regular travel, then it may be expected to target these types of cities as well.

\section{Uber effects on transit ridership}

Given that Uber is not expected to substitute transit on regular trips like daily work commutes, it is not expected to have a significant effect on transit ridership in the short term. In the medium term, Uber may provide an alternative to private car ownership and could be expected to encourage lower levels of car ownership as people adopt and "Uber and Transit" lifestyle. According to a recent market report, Americans are getting a new car every 6.5 years on average (Henry, 2014). Therefore, any evidence of a medium term effect on transit is likely to emerge roughly in this amount of time after Uber's entry.

Moreover, if Uber's $\$ 50$ billion valuation is any indication, investors likely predict that Uber's success is dependent on the company either: 
1. Inducing demand for a significant amount of new trip types,

2. Taking a significant portion of market share away from existing transportation options such as both transit and/or taxis, or

3. A combination of both of these hypotheses (Damodaran, 2015).

Given such a high market valuation, it is most likely that investors are buying into both visions (option 3). Therefore, if the results of this study show that Uber is not demonstrably taking away from the public transit market share, then the $\$ 50$ billion valuation rests on the expectation that Uber is creating demand for additional trips, and likely taking away market share from non-transit transportation services such as taxis. Such a result would also reinforce the conclusions of the Murphy et al. (2016) study. Although such company valuations are not crystal balls that always accurately predict the future (e.g. the 'Dot Com' bubble of the 2000s), they do speak to a trend that in this case warrants investigation in the interest of adequate transit planning and municipal governance.

\subsection{Data Collection}

In order to test these hypotheses, it was necessary to gather data from several sources. This study focuses on the United States due to Uber's early and sustained market presence in American cities and due to the availability of a unified set of data to track transit ridership across those cities.

First, data was collected on the timing of Uber's market entry into major US urban markets. This timeline was estimated using information from Uber's website, and the dates of entry were determined through online research of local media coverage of the service's arrival. In cases where Uber service was partially interrupted due to government intervention and then resumed, Uber's date of entry (for purposes of descriptive statistics) original market entry date was retained. 
Second, data from 2014 US Census Bureau (5-year averages) on various demographic metrics in US Metropolitan Statistical Areas ('MSA') was collected from the U.S. Census Bureau. Census data described median age, sex, income levels, rates of car ownership for commuting workers, and education levels. Although MSA boundaries tend to be very large and go beyond urban cores where Uber trips are most likely generated, MSAs capture the wide variety of travel patterns possibly undertaken in a region by people not necessarily bound to the downtown. Indeed, according to Taylor et al. 2016, TNC "drivers are not restricted to picking up passengers in particular municipalities" (Taylor et al. 2016, 73).

Third, data from the 2014 National Transit Database ('NTD') were used to estimate transit ridership changes over time. The Service Data and Operating Data Time Series dataset was used to observe trends in Passenger Miles Travelled ('PMT') as a way to estimate transit use in different cities, as defined by Urbanized Area ('UZA'). The urban populations and areas provided by the NTD data were used to calculate population densities of the respective UZAs observed in the study. While UZA and MSA boundaries are not identical, almost all public transit trips remain within UZA boundaries while Uber's coverage is more variegated.

\subsection{Methodology}

This study uses descriptive statistics as a way of drawing high-level conclusions about Uber's possible effect on overall ridership trends, limiting transit ridership observations to a 10 -year period from 2005 to 2014 . Although the NTD database does provide ridership information as far back as 1991, Uber only arrived in its first city in 2010 and therefore a 5-year pre-Uber look was deemed sufficient. In the full 10-year period, it was possible to establish the following baseline ridership trends:

- Growth rates in transit ridership across Uber and non-Uber cities;

- Current levels (as of 2014) of transit ridership across Uber and non-Uber cities. 
Cities in the NTD database were grouped according their year of Uber entry ('Uber City Groups'). These groups were first compared based on demographic and socio-economic metrics of population, population density, median income, vehicle ownership, education level, sex, and age. Then, these groups were compared according to their ridership levels over the 10 -year period described.

\section{Establishing baseline trends and Uber city groups}

To adequately compare demographic and ridership information across the areas tracked by the NTD database, the first step was to aggregate ridership information from multiple transit service providers for a combined UZA. For example, the "Chicago, IL-IN" UZA had 17 total transit agencies operating within it- those were aggregated into one "Chicago, IL-IN" UZA for which total ridership trends could be observed. Agencies that did not have full 10-year data starting from 2005 (until 2014) were discounted in the UZA aggregate to mitigate sudden spikes in total ridership levels caused by a new transit system appearing or disappearing.

Once the historic ridership levels for the UZAs were estimated using the NTD data, the cities where Uber is currently operating needed to be matched by name according to those UZAs. Since Uber city names as defined by Uber did not always match up with UZA names, Uber cities in those cases were given special treatment. For example, in Maryland, Uber entered the city of Baltimore in 2013, but Uber entered the adjacent city of Annapolis in 2014 only. They both fall within the Baltimore UZA, so for the purposes of this study it was determined that Uber entered the "Baltimore, MD" UZA in 2013, even though Uber entered other parts of that UZA like Annapolis only a year later. This is a study limitation, along with the underlying assumption in this method that trips originating from an Uber-defined city such as Annapolis might service a rider who lives within the Baltimore UZA but not in a destination area that is not officially serviced by Uber (i.e. outside of "Baltimore" and "Annapolis" according to Uber). 


\section{Quasi 'Difference-in-difference' calculation}

Once these Uber City Groups were finalized, and the demographic comparison of these groups was completed, the next step was to compare ridership levels over time across the Uber City Groups. To determine a benchmark by which to compare ridership growth of these groups, the 'No Uber' group was used analogously to a control group. Thus, those regions in which Uber did not enter serve to provide a benchmark to which "normal transit ridership growth" can be compared for regions entered by Uber. This was done for two reasons:

- To account for the compounding effects of the 2008 economic recession on transit ridership across Uber and non-Uber cities alike.

- To detect differences in ridership growth between the periods before and after Uber entry across different Uber City Groups.

In order to detect these differences, an imperfect "difference in difference" calculation was performed, whereby the ratio between ridership growth in an Uber City Group prior and after Uber entry was compared to the ratio between ridership growth in the control "No Uber" city group in the same time periods. This calculation is represented by the following equation:

$\frac{R_{2014} / R_{U}}{R_{U-1} / R_{2005}} / \frac{N_{2014} / N_{U}}{N_{U-1} / N_{2005}}$

Whereby:

$R=$ Transit ridership levels of given Uber City Group

$U=$ Year of Uber entry of given Uber City Group

$N=$ Transit ridership levels of "No Uber" city group 
As an example, for the 2012 Uber City Group (the group comprised of cities where Uber entered in 2012), the calculation to determine the ratio looks like this (2014 is the most recent year of transit data, and 2005 is the first year of the study period):

$$
\frac{R_{2014} / R_{2012}}{R_{2011} / R_{2005}} / \frac{N_{2014} / N_{2012}}{N_{2011} / N_{2005}}
$$

As will be shown in the results section below, the No Uber city group is characteristically quite different from the group where Uber entered earlier. Therefore, there are certain limitations to this approach given that the No Uber group is not an ideal control group. As a result, this approach functions as a "quasi" difference-in-difference analysis. While this limitation is discussed in the final chapter, the No Uber group still provides an illustrative benchmark by which to compare Uber City Groups to each other. Based on this relative difference measure, values above one indicate that transit ridership grew faster after Uber's entry in an Uber city compared to the relative change in transit ridership growth in non-Uber cities. In contrast, values less than one indicate that transit ridership grew relatively slower in Uber regions after its market entry. 


\section{Chapter 3: Results}

\subsection{Uber city profiles}

\section{Market entries}

The figure below presents all of the UZAs in the USA where Uber was operating at the time of this study, grouped by year of Uber entry into those cities (Uber City Groups). From this table, it is possible to observe that Uber started off in a limited number of cities, and that its growth has been significant in the past two years. Uber targeted highprofile cities in its first years before moving into smaller-profile markets.

Figure 3: All Uber UZAs by year of Uber entry, i.e. Uber City Groups

\begin{tabular}{|c|c|c|c|c|c|c|c|c|}
\hline $\begin{array}{l}\text { UBER } \\
\text { CITY } \\
\text { GROUP }\end{array}$ & & & & & & & & \\
\hline 2010 & $\begin{array}{l}\text { San } \\
\text { Francisco- } \\
\text { Oakland, CA }\end{array}$ & & & & & & & \\
\hline 2011 & $\begin{array}{l}\text { Washington, } \\
\text { DC-VA-MD }\end{array}$ & Chicago, IL-IN & $\begin{array}{l}\text { New York- } \\
\text { Newark, } \\
\text { NY-NJ-CT }\end{array}$ & & & & & \\
\hline 2012 & $\begin{array}{l}\text { Dallas-Fort } \\
\text { Worth- } \\
\text { Arlington, } \\
\text { TX }\end{array}$ & Atlanta, GA & $\begin{array}{l}\text { Boston, } \\
\text { MA-NH-RI }\end{array}$ & $\begin{array}{l}\text { San Diego, } \\
\text { CA }\end{array}$ & $\begin{array}{l}\text { Denver- } \\
\text { Aurora, CO }\end{array}$ & $\begin{array}{l}\text { Los Angeles, } \\
\text { CA }\end{array}$ & $\begin{array}{l}\text { Phoenix- } \\
\text { Mesa, AZ }\end{array}$ & $\begin{array}{l}\text { Minneapolis- } \\
\text { St. Paul, MN- } \\
\text { WI }\end{array}$ \\
\hline \multirow{2}{*}{2013} & $\begin{array}{l}\text { Baltimore, } \\
\text { MD }\end{array}$ & $\begin{array}{l}\text { Charlotte, NC- } \\
\text { SC }\end{array}$ & $\begin{array}{l}\text { Columbus, } \\
\mathrm{OH}\end{array}$ & Detroit, MI & $\begin{array}{l}\text { Oklahoma } \\
\text { City, OK }\end{array}$ & Seattle, WA & $\begin{array}{l}\text { Nashville- } \\
\text { Davidson, TN }\end{array}$ & $\begin{array}{l}\text { Santa } \\
\text { Barbara, CA }\end{array}$ \\
\hline & $\begin{array}{l}\text { Indianapolis, } \\
\text { IN }\end{array}$ & Honolulu, $\mathrm{HI}$ & Tucson, AZ & $\begin{array}{l}\text { Providence, } \\
\text { RI-MA }\end{array}$ & Trenton, NJ & & & \\
\hline \multirow{5}{*}{2014} & Akron, $\mathrm{OH}$ & $\begin{array}{l}\text { Albuquerque, } \\
\text { NM }\end{array}$ & $\begin{array}{l}\text { Amarillo, } \\
\text { TX }\end{array}$ & $\begin{array}{l}\text { Ann Arbor, } \\
\text { MI }\end{array}$ & $\begin{array}{l}\text { Asheville, } \\
\text { NC }\end{array}$ & $\begin{array}{l}\text { Athens- } \\
\text { Clarke } \\
\text { County, GA }\end{array}$ & Wichita, KS & Austin, TX \\
\hline & $\begin{array}{l}\text { Bakersfield, } \\
\text { CA }\end{array}$ & Bangor, ME & $\begin{array}{l}\text { Cincinnati, } \\
\text { OH-KY-IN }\end{array}$ & $\begin{array}{l}\text { New } \\
\text { Orleans, LA }\end{array}$ & Hartford, CT & $\begin{array}{l}\text { Portland, } \\
\text { ME }\end{array}$ & $\begin{array}{l}\text { Blacksburg, } \\
\text { VA }\end{array}$ & $\begin{array}{l}\text { Sarasota- } \\
\text { Bradenton, } \\
\text { FL }\end{array}$ \\
\hline & $\begin{array}{l}\text { Cleveland, } \\
\mathrm{OH}\end{array}$ & $\begin{array}{l}\text { College } \\
\text { Station-Bryan, } \\
\text { TX }\end{array}$ & $\begin{array}{l}\text { Burlington, } \\
\text { VT }\end{array}$ & Raleigh, NC & Durham, NC & $\begin{array}{l}\text { Charleston- } \\
\text { North } \\
\text { Charleston, } \\
\text { SC }\end{array}$ & $\begin{array}{l}\text { Chattanooga, } \\
\text { TN-GA }\end{array}$ & $\begin{array}{l}\text { Greenville, } \\
\text { SC }\end{array}$ \\
\hline & $\begin{array}{l}\text { Columbia, } \\
\text { MO }\end{array}$ & Charleston, SC & $\begin{array}{l}\text { Riverside- } \\
\text { San } \\
\text { Bernardino, } \\
\text { CA }\end{array}$ & $\begin{array}{l}\text { Corpus } \\
\text { Christi, TX }\end{array}$ & $\begin{array}{l}\text { Des Moines, } \\
\text { IA }\end{array}$ & $\begin{array}{l}\text { El Paso, TX- } \\
\text { NM }\end{array}$ & $\begin{array}{l}\text { Fayetteville- } \\
\text { Springdale- } \\
\text { Rogers, AR- } \\
\text { MO }\end{array}$ & $\begin{array}{l}\text { Fayetteville, } \\
\text { NC }\end{array}$ \\
\hline & Flagstaff, AZ & Flint, MI & Miami, FL & $\begin{array}{l}\text { Cape Coral, } \\
\text { FL }\end{array}$ & Fresno, CA & $\begin{array}{l}\text { Gainesville, } \\
\text { FL }\end{array}$ & $\begin{array}{l}\text { Grand } \\
\text { Rapids, MI }\end{array}$ & $\begin{array}{l}\text { Green Bay, } \\
\text { WI }\end{array}$ \\
\hline
\end{tabular}




\begin{tabular}{|c|c|c|c|c|c|c|c|c|}
\hline & $\begin{array}{l}\text { Greensboro, } \\
\text { NC }\end{array}$ & $\begin{array}{l}\text { Norfolk-- } \\
\text { Virginia Beach- } \\
\text {-Newport } \\
\text { News, VA }\end{array}$ & $\begin{array}{l}\text { Houston, } \\
\text { TX }\end{array}$ & $\begin{array}{l}\text { Kansas City, } \\
\text { MO-KS }\end{array}$ & Jackson, MS & $\begin{array}{l}\text { Jacksonville, } \\
\text { FL }\end{array}$ & $\begin{array}{l}\text { Jacksonville, } \\
\text { NC }\end{array}$ & $\begin{array}{l}\text { Kalamazoo, } \\
\text { MI }\end{array}$ \\
\hline & $\begin{array}{l}\text { Knoxville, } \\
\text { TN }\end{array}$ & Lafayette, LA & $\begin{array}{l}\text { Lexington- } \\
\text { Fayette, KY }\end{array}$ & Lincoln, NE & Lubbock, TX & $\begin{array}{l}\text { Madison, } \\
\text { WI }\end{array}$ & $\begin{array}{l}\text { Memphis, } \\
\text { TN-MS-AR }\end{array}$ & $\begin{array}{l}\text { Milwaukee, } \\
\text { WI }\end{array}$ \\
\hline & $\begin{array}{l}\text { Modesto, } \\
\text { CA }\end{array}$ & $\begin{array}{l}\text { Bonita Springs, } \\
\text { FL }\end{array}$ & $\begin{array}{l}\text { South } \\
\text { Bend, IN- } \\
\text { MI }\end{array}$ & $\begin{array}{l}\text { Little Rock, } \\
\text { AR }\end{array}$ & Ocala, FL & $\begin{array}{l}\text { Omaha, NE- } \\
\text { IA }\end{array}$ & Orlando, FL & Oxnard, CA \\
\hline & $\begin{array}{l}\text { Pensacola, } \\
\text { FL-AL }\end{array}$ & Richmond, VA & $\begin{array}{l}\text { Tampa-St. } \\
\text { Petersburg, } \\
\text { FL }\end{array}$ & $\begin{array}{l}\text { Portland, } \\
\text { OR-WA }\end{array}$ & Reno, NV-CA & $\begin{array}{l}\text { Roanoke, } \\
\text { VA }\end{array}$ & $\begin{array}{l}\text { Salt Lake } \\
\text { City-West } \\
\text { Valley City, } \\
\text { UT }\end{array}$ & $\begin{array}{l}\text { San Antonio, } \\
\text { TX }\end{array}$ \\
\hline & $\begin{array}{l}\text { San Luis } \\
\text { Obispo, CA }\end{array}$ & Santa Fe, NM & $\begin{array}{l}\text { Spokane, } \\
\text { WA }\end{array}$ & $\begin{array}{l}\text { Tallahassee, } \\
\text { FL }\end{array}$ & $\begin{array}{l}\text { Toledo, } \mathrm{OH}- \\
\mathrm{MI}\end{array}$ & Tulsa, OK & $\begin{array}{l}\text { Tuscaloosa, } \\
\mathrm{AL}\end{array}$ & Waco, TX \\
\hline & $\begin{array}{l}\text { Wilmington, } \\
\text { NC }\end{array}$ & $\begin{array}{l}\text { Worcester, } \\
\text { MA-CT }\end{array}$ & & & & & & \\
\hline \multirow{5}{*}{2015} & Abilene, TX & $\begin{array}{l}\text { Augusta- } \\
\text { Richmond } \\
\text { County, GA-SC }\end{array}$ & Ames, IA & $\begin{array}{l}\text { Los } \\
\text { Angeles- } \\
\text { Long } \\
\text { Beach- } \\
\text { Anaheim, } \\
\text { CA }\end{array}$ & $\begin{array}{l}\text { Philadelphia, } \\
\text { PA-NJ-DE- } \\
\text { MD }\end{array}$ & $\begin{array}{l}\text { Bellingham, } \\
\text { WA }\end{array}$ & Rockford, IL & $\begin{array}{l}\text { Birmingham, } \\
\mathrm{AL}\end{array}$ \\
\hline & $\begin{array}{l}\text { Bowling } \\
\text { Green, KY }\end{array}$ & $\begin{array}{l}\text { Charlottesville, } \\
\text { VA }\end{array}$ & $\begin{array}{l}\text { Coeur } \\
\text { d'Alene, ID }\end{array}$ & Dayton, $\mathrm{OH}$ & Erie, PA & $\begin{array}{l}\text { Fargo, ND- } \\
\text { MN }\end{array}$ & $\begin{array}{l}\text { Fort Wayne, } \\
\text { IN }\end{array}$ & $\begin{array}{l}\text { St. Louis, } \\
\text { MO-IL }\end{array}$ \\
\hline & $\begin{array}{l}\text { Pittsburgh, } \\
\text { PA }\end{array}$ & $\begin{array}{l}\text { Harrisonburg, } \\
\text { VA }\end{array}$ & $\begin{array}{l}\text { Idaho Falls, } \\
\text { ID }\end{array}$ & $\begin{array}{l}\text { Scranton, } \\
\text { PA }\end{array}$ & $\begin{array}{l}\text { Lancaster, } \\
\text { PA }\end{array}$ & $\begin{array}{l}\text { Las Cruces, } \\
\text { NM }\end{array}$ & $\begin{array}{l}\text { Las Vegas- } \\
\text { Henderson, } \\
\text { NV }\end{array}$ & $\begin{array}{l}\text { Lawrence, } \\
\text { KS }\end{array}$ \\
\hline & $\begin{array}{l}\text { Manhattan, } \\
\text { KS }\end{array}$ & Odessa, TX & Mobile, AL & Peoria, IL & Reading, PA & $\begin{array}{l}\text { Savannah, } \\
\text { GA }\end{array}$ & $\begin{array}{l}\text { Springfield, } \\
\text { IL }\end{array}$ & $\begin{array}{l}\text { Springfield, } \\
\text { MA--CT }\end{array}$ \\
\hline & $\begin{array}{l}\text { State } \\
\text { College, PA }\end{array}$ & Topeka, KS & $\begin{array}{l}\text { Yuma, AZ- } \\
\text { CA }\end{array}$ & & & & & \\
\hline
\end{tabular}

At the time of this study, Uber was operating in 142 total UZAs that had full 10-year data. Uber first started in San Francisco in 2010, before entering the Chicago, New York City, and Washington, DC markets in 2011. In 2012, Uber entered 8 more cities, followed by 13, 82, and 35 more cities from 2013 to 2015 respectively. There were 121 "No Uber" cities that were analyzed in this study as well. 


\section{Median incomes}

The graph below shows the average of all median household incomes in Uber City Groups. The "No Uber" group refers to the remainder of UZAs in the USA that did not have Uber at the time of this study.

Figure 4: Uber City Groups by median household income*

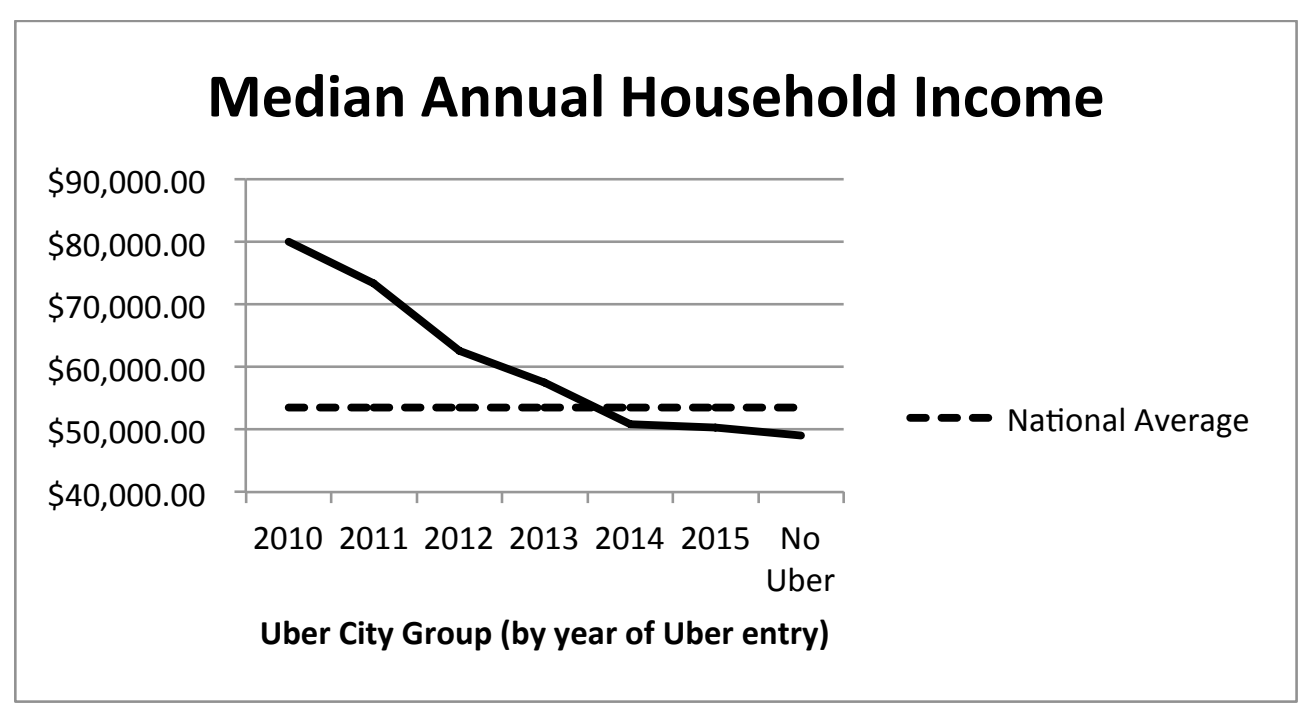

*2010 only represents San Francisco

Uber first entered cities where median household income is highest, while progressing into markets with increasingly lower median household incomes. The remaining markets where Uber has not yet entered have median household incomes that are lower than the national average. 


\section{Population density}

The graph below shows the average population density per square mile for Uber City Groups sorted by year of Uber entry.

Figure 5: Uber City Groups by population density*

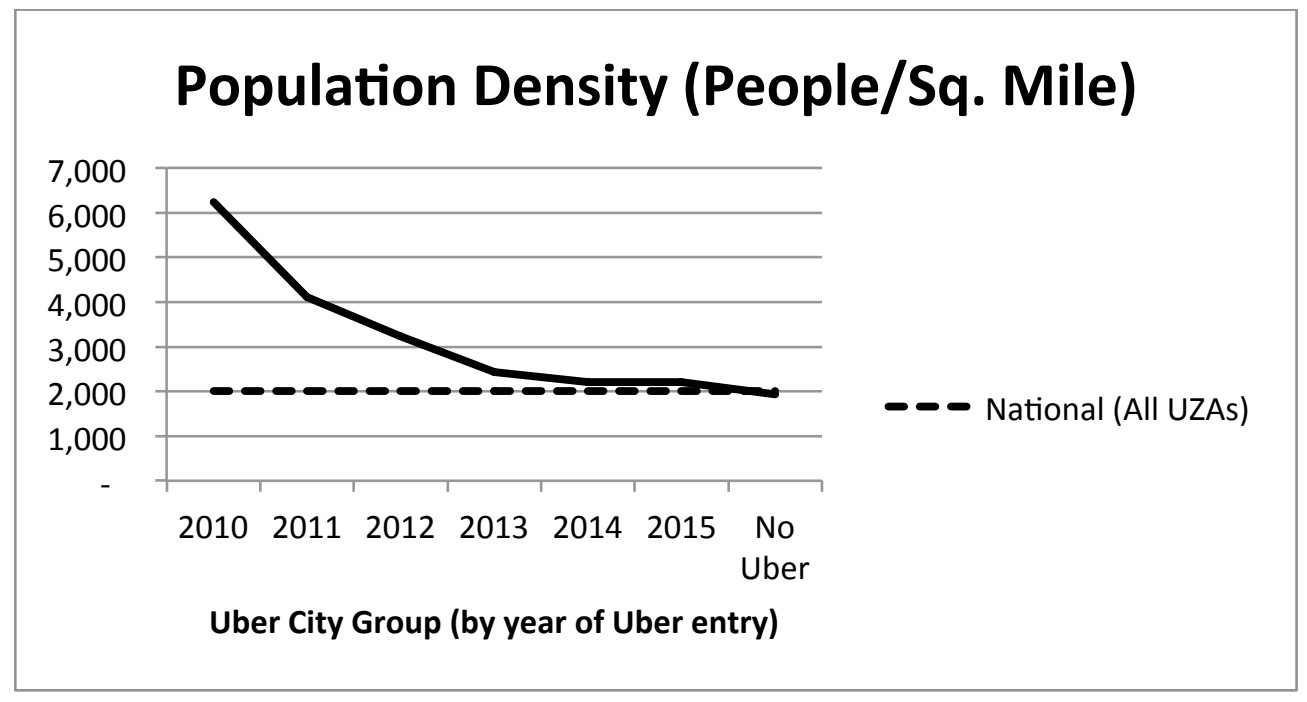

*2010 only represents San Francisco

Uber first entered denser than average cities, and then progressed into markets where population density was increasingly lower. The remainder of cities where Uber has not yet entered has a lower, albeit slight, average population density than Uber cities. 


\section{Educational attainment}

The graph below shows the average percentage of population with a bachelor degree or higher in Uber City Groups.

Figure 6: Uber City Groups by percentage of bachelor degree or higher*

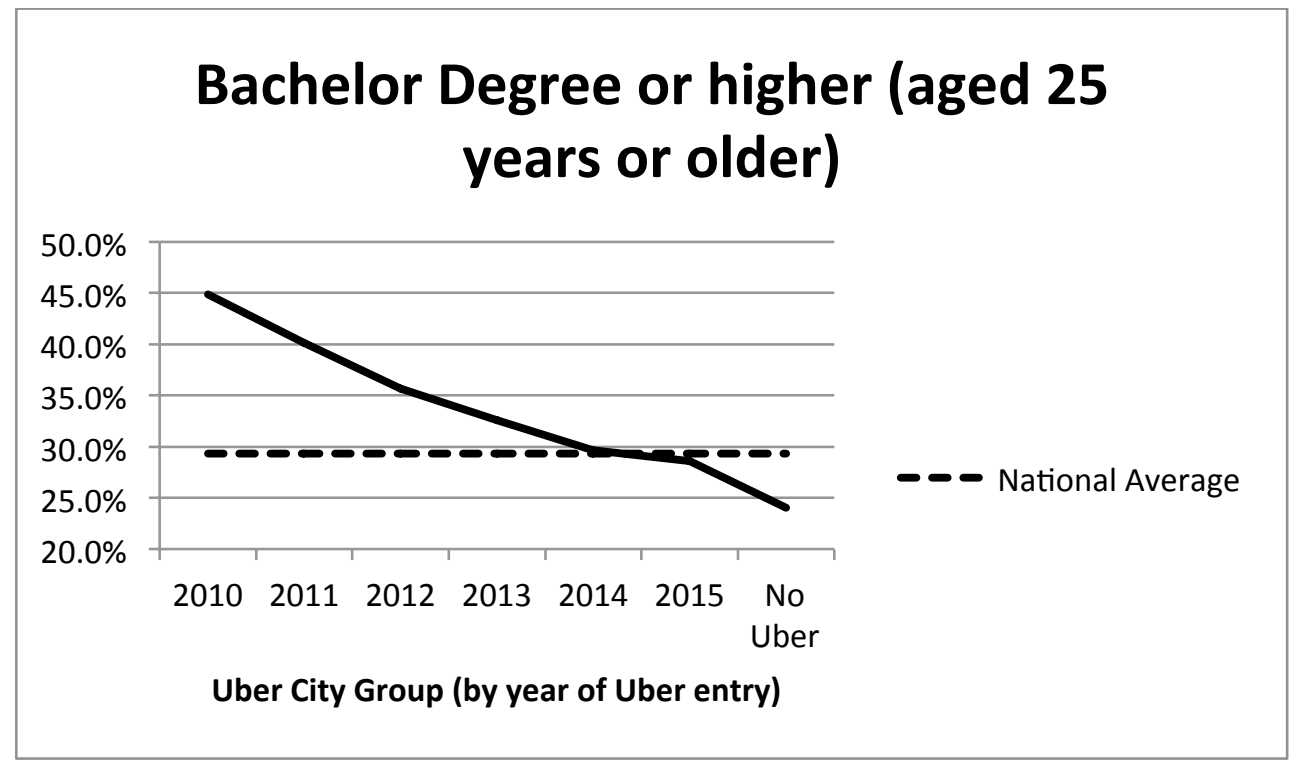

*2010 only represents San Francisco

Uber first entered markets where there were higher than national average levels of education as measured by percentage of population with bachelor degree or higher, and progressed into markets where educational attainment was lower. 


\section{Median age}

The graph below shows the average median age across Uber City Groups.

Figure 7: Uber City Groups by median age*

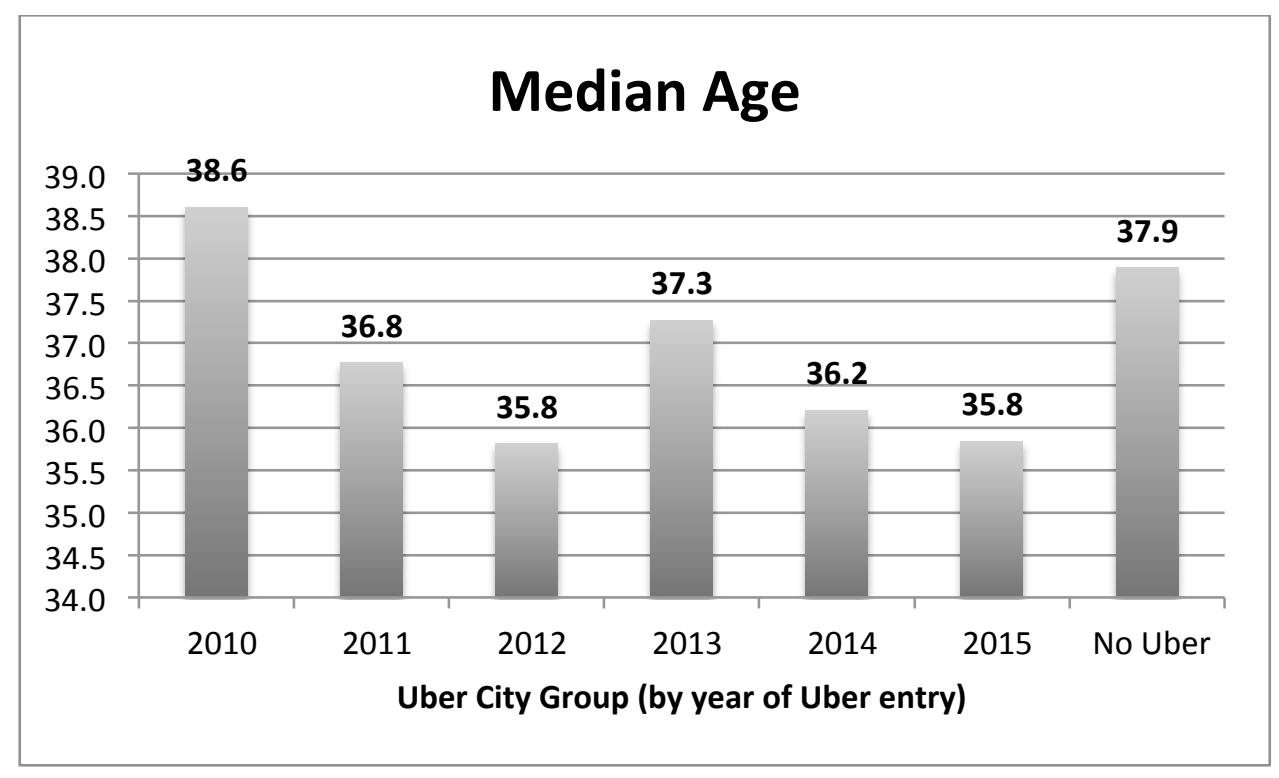

*2010 only represents San Francisco

Median ages of the groups are varied and not likely to be a significant indicator of where Uber targets the market. 


\section{Vehicle ownership}

The graph below shows the average vehicle ownership rates of working commuters in Uber City Groups.

Figure 8: Uber City Groups by rates of car ownership among working commuters

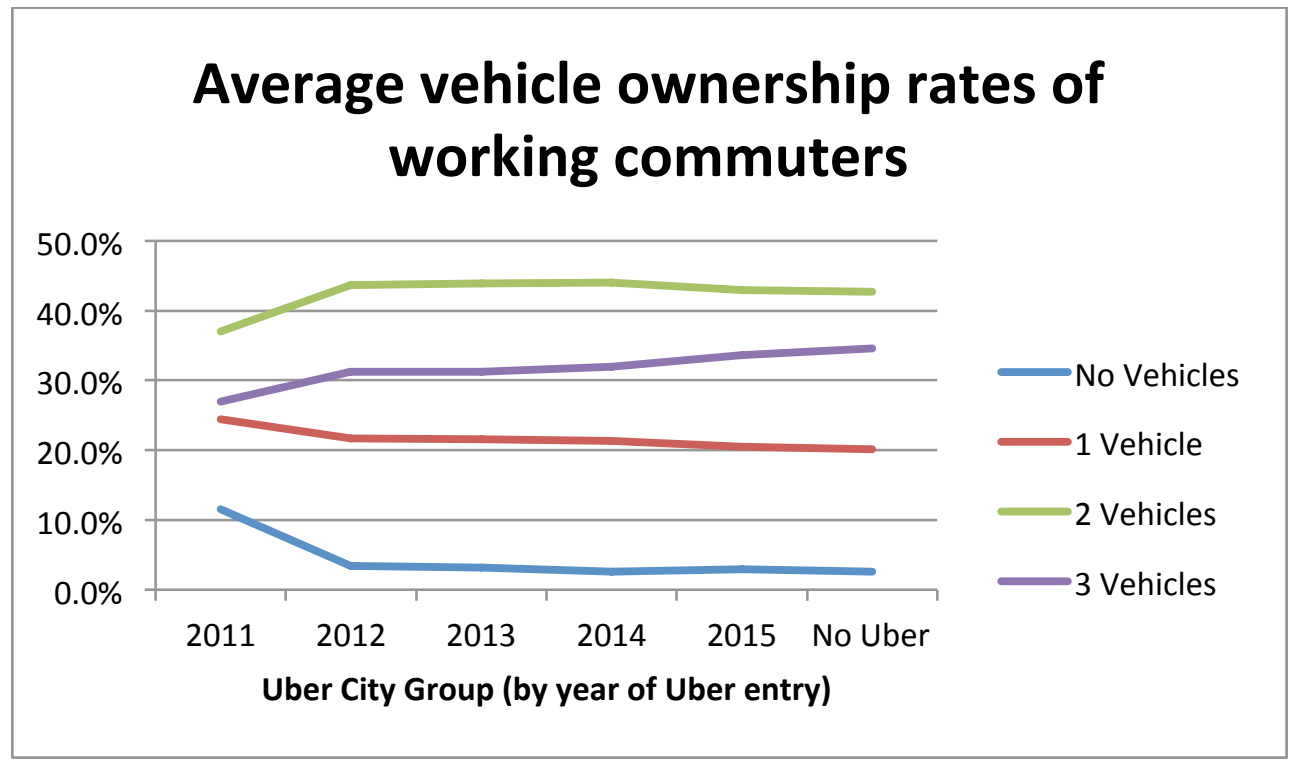

Uber first entered markets where rates of low vehicle ownership (0-1 cars) were highest, and where rates of higher vehicle ownership (2-3) cars were lowest. 


\section{Principal industries of employment}

The graph below shows the average rates of employment in four notable industries across UZA groups sorted by year of Uber entry. The color-coded dotted lines represent the national averages of employment in the respective industries.

Figure 9: Uber city groups by percentage of working population by industry

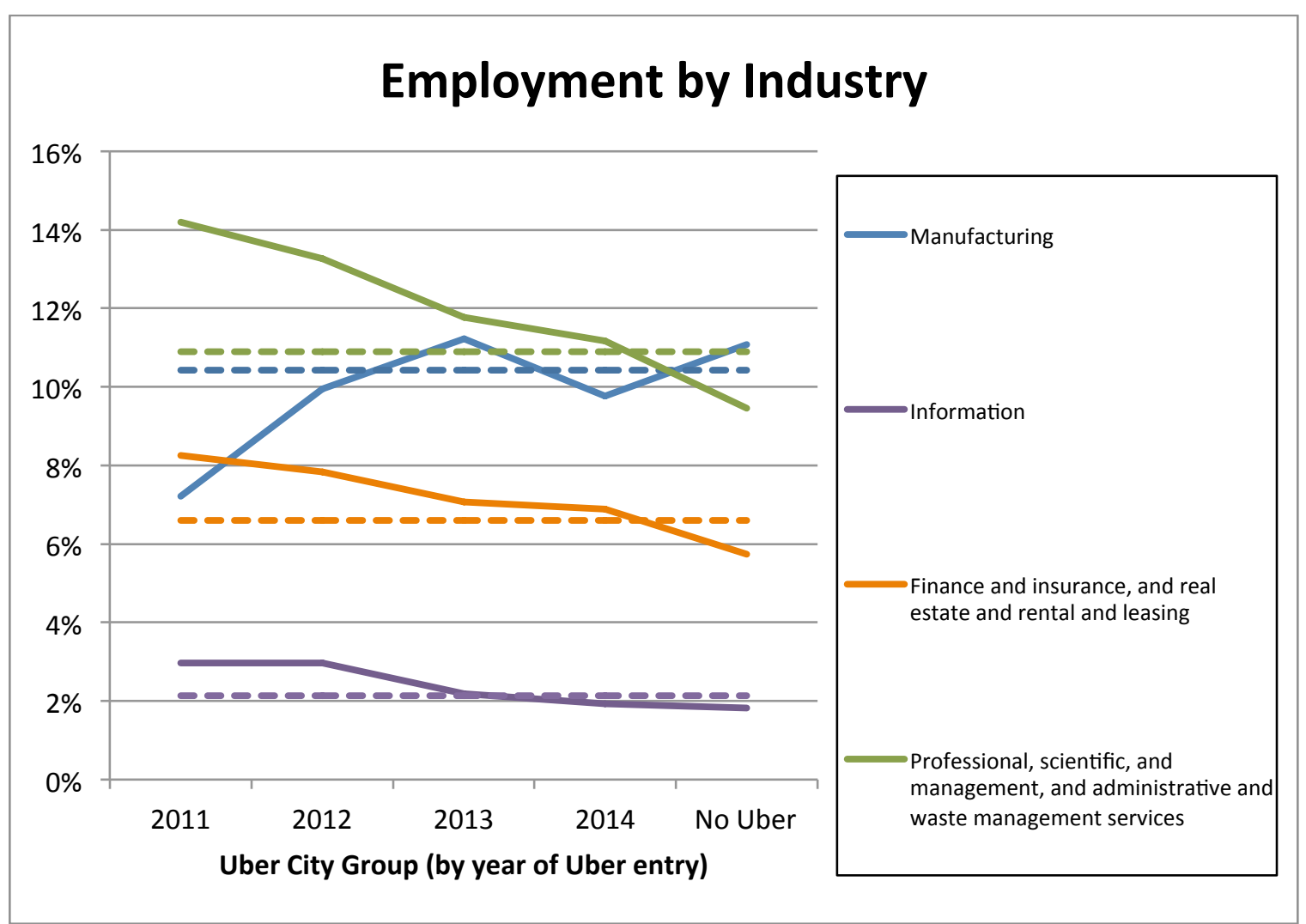

Uber first targeted cities with higher than average percentages of workers in the Information, Finance, and Professional services. It has only recently been entering markets with higher levels of workers in the manufacturing industry.

While initially targeting markets where there was higher than average levels of median income, population density, educational attainment, low vehicle ownership rates, and white collar jobs, Uber has since ventured into markets that are closer or lower than national average in all of those categories. 


\subsection{Effects on transit ridership}

\section{Current-day ridership snapshot}

The chart below presents a current day look at ridership levels across Uber and nonUber cities, as measured by average passenger miles travelled per capita.

Figure 10: Current day transit ridership levels across Uber and non-Uber cities

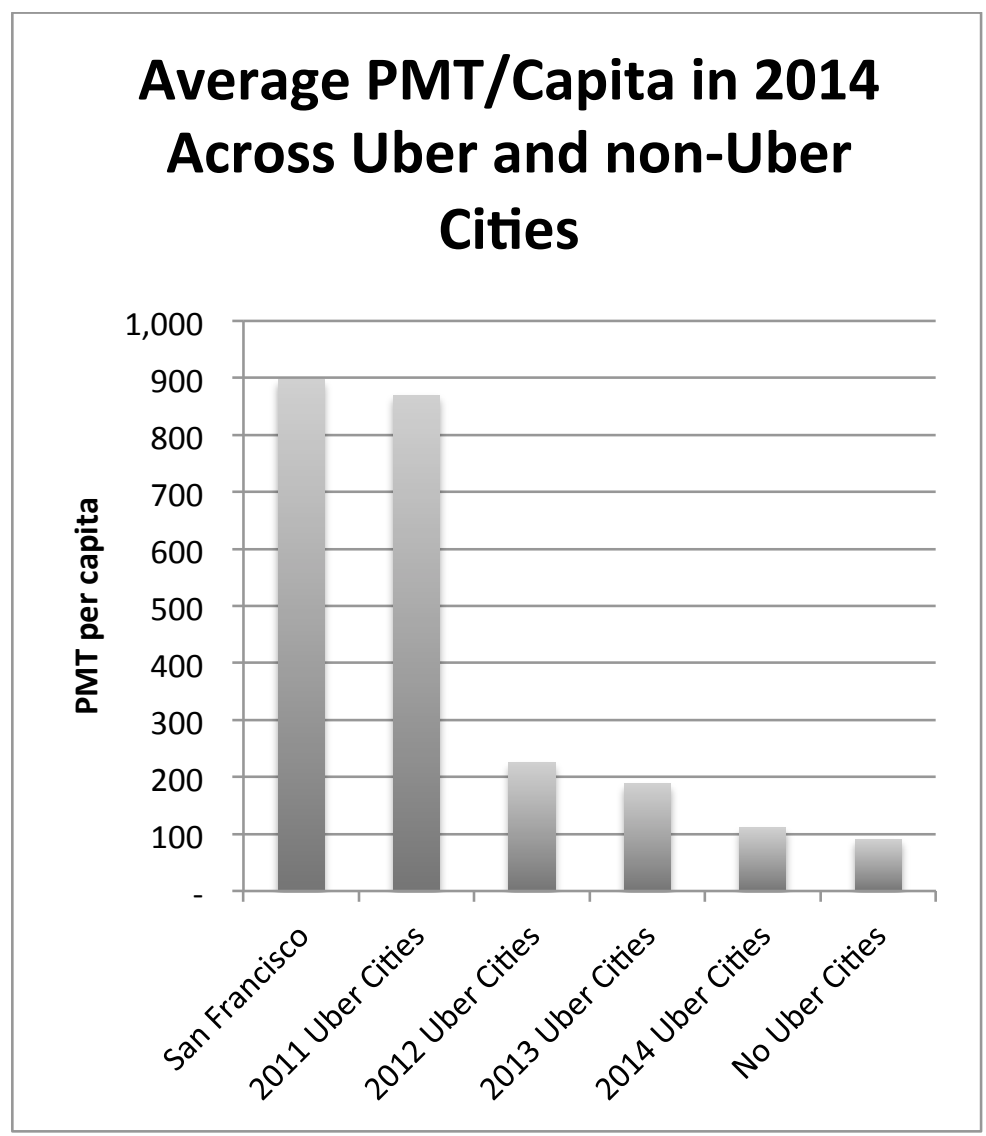

Uber first targeted cities with higher ridership levels than the ones Uber entered starting in 2012 and later. Cities still without Uber have the lowest levels of per capita PMT compared to the other Uber city groups. This suggests that Uber's preference for large, dense cities was not outweighed by the presence in those cities of robust transit networks. 


\section{Actual ridership vs. benchmark}

The graph below shows the comparison of ridership levels across different Uber City Groups over a 10-year period.

Figure 11: Transit ridership measured by PMT per capita over a 10-year period for Uber City Groups (by year of Uber entry)

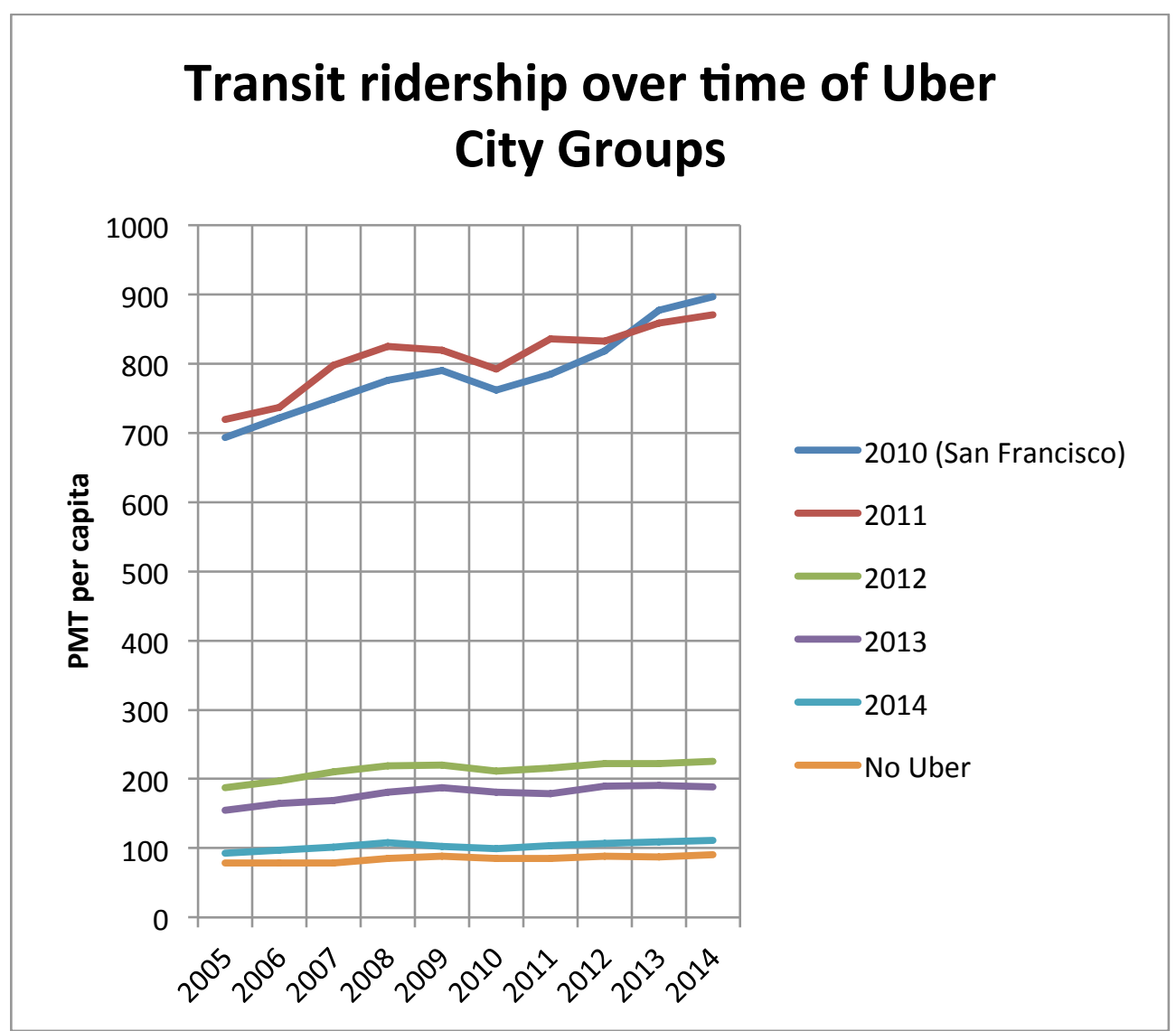

From this graph, it can be observed that the cities that Uber first targeted (the 2010 and 2011 Uber City Groups) all have higher rates of ridership growth, both before and after the recession. The other groups have less dramatic levels of ridership growth, but can all be observed to have been somewhat increasing before the recession, and either mildly increasing or remained stable after the recession. All groups, including cities without Uber, shared a similar fate in transit ridership levels after the 2008 the recession. In order to compare differences in ridership growth between different Uber city groups, it 
is therefore possible to use the No Uber group as the benchmark group that was not "treated" with Uber. The results of this analysis are shown in the following graph.

Figure 12: Ridership growth of Uber cities compared to No Uber cities*

\section{Transit ridership growth of Uber Cities by year of Uber entry compared to cities without Uber}

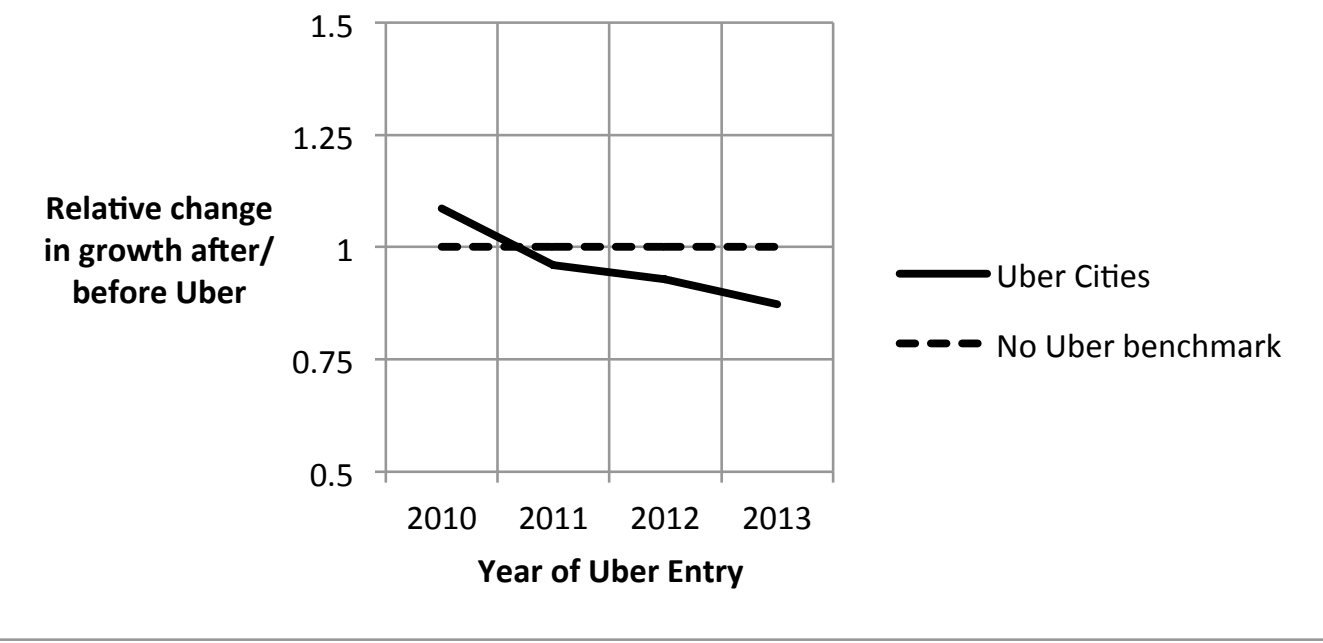

*Equation used to calculate values: $\frac{R_{2014} / R_{U}}{R_{U-1} / R_{2005}} / \frac{N_{2014} / N_{U}}{N_{U-1} / N_{2005}}$

$R=$ Transit ridership levels of given Uber City Group

$U=$ Year of Uber entry of given Uber City Group

$N=$ Transit ridership levels of "No Uber" city group

The different relative ridership growth rates shown in this graph have two potential explanations. The first is that Uber's entry in a regional transportation market appears to be associated with a reduction in transit ridership growth that attenuates over time. In fact, insofar that the attenuating effect and experiences of the earliest adopting cities are representative (there is only one city in the $\mathbf{2 0 1 0}$ group, and three in the 2011 group), Uber's apparent link with short-term reductions in transit ridership may even lead to medium-term ridership gains (over approximately five years) as a region's fuller transportation market and users adapt. Such a finding would be consistent with Uber 
directly substituting for other modes in a short-term period and medium-term user adaptations (car ownership or housing choice decisions) leading Uber to be a complement to transit ridership-or at least a less perfect substitute.

The second potential explanation of these results is that Uber impacts city groups differently based on other regional characteristics. Based on the results shown in Figure 12 , Uber's entry into a regional transportation market with cities that are less dense, affluent, and educated appears to be associated with a reduction in transit ridership growth. The Uber city group profiles established in section 3.1 show that the cities where Uber entered first are structurally different than the ones where Uber entered more recently. This suggests that the cities where Uber entered earlier have characteristics that make Uber less of a substitute to transit than cities that Uber has entered more recently. Given that transit in the latter group of cities is likely less competitive in terms of service quality than the former group, transit ridership in the latter group may be more vulnerable to Uber.

These results and their two potential explanations must be nuanced by the limitations of the data and methods used in this study. The following chapter discusses the implications of these findings and their limitations. 


\section{Chapter 4: Conclusions and Recommendations}

\subsection{Conclusions}

Uber city profiles - Uber prefers dense, affluent cities, but is now entering other types of markets

Uber was expected to initially prefer larger cities with denser populations where there is a greater market for unique destination trips before moving to smaller markets. Findings are consistent with these expectations, as Uber is increasingly moving to smaller and less dense urban markets.

While the results showed no visible pattern regarding median age of Uber cities (Figure 7), urban density and car ownership are strongly linked with Uber's market entry. Uber first entered cities with the highest population densities of all Uber City Groups (Figure 5), and cities with the lowest levels of car ownership (Figure 8). Once Uber entered those initial cities, the company then entered cities with lower densities and higher levels of car ownership. Uber first targeted cities with highest levels of median income (Figure 4), highest educational attainment levels (Figure 6), and highest share of whitecollar jobs (Figure 9), and has slowly transitioned to other urban markets. Uber initially targeted cities that have high levels of transit ridership overall (Figure 10) where transit ridership growth has historically also been strongest. Although this might suggest that Uber preferred cities with established transit systems, these transit systems might be a by-product of other city properties that Uber finds attractive, such as city size, urban density, affluence, and industrial base. Uber shows a clear preference for dense affluent cities, but given that it has entered 117 less dense, less affluent cities in 2014 and 2015, it appears that it is finding a market potential in most cities, regardless of their spatial, demographic, or socio-economic characteristics. 


\section{Ridership trends - Uber's links with transit ridership vary either by regional context or by time period}

The results of the illustrative difference-in-difference analysis suggest that Uber appears to:

- Be more of a complement (or less of a substitute) over time,

- Be more of a complement (or less of a substitute) in large, dense regions with highly educated, affluent, productive labour markets that already have very high transit ridership, or

- Be a combination of the two.

If the data from the relatively small sample size of 2010 and 2011 Uber city groups is representative, transit ridership in these groups where Uber entered first increases after a period of roughly 5 years, approximately correlating with the average turnover of vehicle ownership. This suggests that Uber may have an effect on medium term mobility-housing bundle decision-making- in other words, residents in cities with Uber may be influenced by the arrival of the service in determining where to live within a city and how to get around. However, a more robust statistical model would be needed to substantiate this claim.

The conclusion that Uber's recent entry into cities that are less dense, affluent, and educated appears to be associated with a reduction in transit ridership means that Uber is likely substituting transit for more than just occasional trips in these types of cities. This conclusion somewhat contrasts with those proposed by the Murphy et al. (2016) study discussed in Chapter 2, that concluded that Uber serves trip types different from the ones served by transit. This study has shown that Uber likely serves some trip types similar to transit in those less dense cities. However in more dense cities that have had Uber longer, transit trips do not appear to be substituted by Uber. 
Despite certain limitations in terms of the data used and methodology, the conclusions derived from this study can inform discussion on the role of public transit agencies, municipal governments, and policy makers in dealing with Uber.

\subsection{Recommendations}

The results of this study highlight the need for transport planning agencies, municipal governments, and policy makers to understand how Uber is affecting their transit ridership and plan, debate, and regulate accordingly, particularly since the emergence of Uber may be a symptom of a city's larger mobility problems.

\section{Wait time needed}

Given that Uber may be a complement to transit over time in certain types of cities, it should be given the time to mature. Thwarting its development by over-regulating it may prevent cities from enjoying the benefits of the added mobility and transit-centred lifestyles enabled by Uber. This is not to suggest that Uber deserves no regulation relating to the safety of Uber users and drivers.

\section{Regulation in different spatial contexts}

The results of this study have shown that Uber may be more of a complement to public transit over time (or less of a substitute) in large, dense regions with highly educated, affluent, productive labour markets that already have very high transit ridership. But in other cities, Uber may be having more of a substitute effect. If the correct and unique explanation of these results is that Uber's effect on ridership attenuates over time regardless of spatial characteristics, then cities that are less highly educated, dense, and affluent may also need to wait for Uber's negative short-term effect to wear out. However, if the correct and unique explanation is that spatial characteristics are the significant predictor in Uber's effect on transit, then less dense, less educated, and less affluent cities need to pay more attention to Uber than their denser city counterparts. Both of these explanations merit further investigation using more empirical data over 
time. However, since the pressure to act on Uber is immediate, cities to not have the luxury of waiting for five more years of data.

\section{Uber should not become "too big to fail"}

This leads to additional concerns, mainly having to do with the fact that Uber is a private company offering a service that potentially initially takes demand away from a publicly run and ensured service. In the event that Uber went out of business after having been in a city for more than a medium-term period, and large portions of that city's population have adopted a transit-centred lifestyle that now relies on Uber for certain trip types, then those residents may suddenly find themselves lacking a core element of their overall mobility.

Barriers of entry into the ridesourcing market are relatively low (Sullivan, 2015). Competitors such as Lyft or others may overtake Uber and continue to populate the market, but cities embracing the arrival of TNCs like Uber should be aware of risks inherent in the profit motive driving the provision of basic mobility needs. Solutions may lie in encouraging fair competition and ensuring operational compatibility with public transit.

\subsection{Study limitations and directions for future research}

This study has limitations in terms of the methods employed and the nature of data on a very recent phenomenon, but a better understanding of the links between transit ridership and TNCs is important for transportation planning, making more in-depth future studies critical for shaping better public policy. This study used descriptive statistics as a method for drawing conclusions. While certain tactics were employed to account for the likely effect of spatial, demographic, and socio-economic factors on transit ridership trends- such as the use of spatially dissimilar Non-Uber cities as a comparative benchmark- future studies with greater resources may benefit from a regression analysis to specifically account for these factors, and other non-Uber factors 
that may be having an effect on transit ridership in an attempt to approach a causal relationship between Uber and travel behaviour. Discounting ridership data from agencies that were not in operation from the full 2005-2014 study period is also a limitation that could be accounted for in a future regression-based analysis.

The data used in this study should also nuance some of the conclusions drawn from it. The demographic data used to contextualize the different Uber City Groups was derived from MSA demographic data, and applied to smaller UZAs. Given that UZAs within an MSA may vary demographically, this is an imperfect representation of the true demographics of the UZAs examined. Using ridership data at the UZA level is perhaps not ideal either. Given that Uber-defined boundaries and UZAs do not line up exactly, it is possible that Uber's true effect on ridership is diluted in a larger UZA area, affecting the results of this study.

Given that Uber only entered into one city in 2010, into three cities in 2011, and into eight in 2012, the results of this study are likely not statistically significant. Since the average car exchange rate is about 6.5 years, medium term effects may barely be visible today. It would be very insightful to repeat this study in 5 years to better understand how larger Uber City Groups like the 2014 or 2015 groups have evolved as a result of Uber-assuming that Uber is still operating, or that a similar company has replaced it. At that point in the future, looking at levels of car ownership would also be helpful to confirm or rebuke the claim that Uber leads to lower levels of car ownership in the medium term.

The greatest asset to any future research on Uber would be Uber ridership data, which would directly describe average trip lengths, types, time of day, and how frequently users are using the service. Although Uber claims that releasing such data would be in violation of user privacy, finding some mechanism to make this information available 
would go a long way in enriching the discussion around Uber's true effects on all other modes of transit, and perhaps engender a more favorable regulatory climate. 


\section{References}

Aber (2016). "Find a City". Retrieved from: https://www.uber.com/cities/

Alba, Davey (2015). “Airbnb Confirms \$1.5 Billion Funding Round, Now Valued At \$25.5 Billion". Wired. Retrieved from: http://www.wired.com/2015/12/airbnb-confirms-15-billion-funding-round-now-valued-at-25-5-billion/

CNW (2015). "Poll suggests UberX is decreasing TTC and GO transit ridership". Retrieved from: http://www.newswire.ca/news-releases/poll-suggests-uberx-is-decreasingttc-and-go-transit-ridership-529475091.html

Cohen, Josh (2015). “Is Uber Really Alt Transportation?” Next City. Retrieved from: https://nextcity.org/daily/entry/uber-alt-transportation-taxi-public-transit

D’Onfro, Jillian (2015). “SpaceX Is Now Worth More Than Dropbox, Snapchat, Or Airbnb". Business Insider. Retrieved from: http://www.businessinsider.com/spacex-valuation-12-billion-2015-1

Damodaran, Aswath (2015). “How Do You Value A Company Like Uber?” Tech Crunch. Retrieved from: http://techcrunch.com/2015/10/10/valuing-uber/

DART (2015). “Uber stepping up "complete trip" efforts" Retrieved from: http://www.dart.org/news/news.asp?ID=1179

Donahue, Kate (2015). "Uber and Public Transit Working Hand in Hand in San Diego". Uber Newsroom. Retrieved from: https://newsroom.uber.com/us-california/uberand-public-transit-working-hand-in-hand-in-san-diego/ 
Ericsson (2015). “Ericsson Mobility Report: 70 percent of world's population using smartphones by 2020" Retrieved from: http://www.ericsson.com/news/1925907

Gandel, Stephen (2015). “Uber just beat Facebook's $\$ 50$ Billion record”. Fortune Magazine. Retrieved from: http://fortune.com/2015/07/31/uber-valuationfunding-round/

Gilbert, Ben (2015). "Uber's CEO gave us a lot of clues about what the future looks like". Tech Insider. Retrieved from: http://www.techinsider.io/ubers-future-is-driverlesscars-2015-9

Grief, Amy (2016). "Uber draws Ire for surge pricing during TTC mess". BlogTO.

Retrieved from:

http://www.blogto.com/city/2016/03/uber_draws_ire_for_surge_pricing_during_ ttc_mess/

Haider et al. (2015). "To Uber or Not to Uber: That is the Question". Retrieved from: http://stream1.newswire.ca/media/2015/09/29/20150929_C6395_PDF_EN_5089 57.pdf

Henry, Jim (2014). “The Average Trade-In Has Stopped Aging So Fast, Great News For The Auto Industry". Forbes. Retrieved from: http://www.forbes.com/sites/jimhenry/2014/05/31/the-average-trade-in-hasstopped-aging-so-fast-great-news-for-the-auto-industry/\#561e0421152d

Liston, Barbara (2016). "Uber teams with Florida city on public transit test". Reuters. Retrieved from: http://www.reuters.com/article/us-uber-tech-subsidiesidUSKCNOW52LQ 
Martin, E. and Shaheen, S. (2011). The Impact of Carsharing on Household Vehicle Ownership. Access, Number 38, Spring 2011.

Mui, Chunka (2016). "The Virtuous Cycle Between Driverless Cars, Electric Vehicles And Car-Sharing Services". Forbes. Retrieved from:

http://www.forbes.com/sites/chunkamui/2016/02/08/the-virtuous-cyclebetween-driverless-cars-electric-vehicles-and-car-sharing-services/\#699486e31c6c

Murphy et al. (2016). Shared-Use Mobility and the Transformation of Public Transit. American Public Transportation Association. Retrieved from: http://www.apta.com/resources/hottopics/Pages/Shared-Use-Mobility.aspx

National Transit Database (2016). Service Data and Operating Data Time Series, 2014 data. Retrieved from: http://www.ntdprogram.gov/ntdprogram/data.htm

Normandin, P.A. and Croteau, M. (2016). “Denis Coderre fustige le refus d'Uber de suspendre son service". La Presse. Retrieved from: http://www.lapresse.ca/actualites/montreal/201602/10/01-4949125-deniscoderre-fustige-le-refus-duber-de-suspendre-son-service.php

Rayle, L. et al (2014). App-Based, On Demand Ride Services: Comparing Taxi and Ridesourcing Trips and User Characteristics in San Francisco. University of California, Berkeley, University of California Transportation Center.

Silvertein, Sara (2014). "These Animated Charts Tell You Everything About Uber Prices in 21 Cities". Business Insider. Retrieved from: http://www.businessinsider.com/ubervs-taxi-pricing-by-city-2014-10 
Simmons, Andria (2015). "MARTA pilots free Wi-Fi on buses and Uber partnership". AJC. Retrieved from: http://commuting.blog.ajc.com/2015/07/23/marta-pilots-free-wifi-on-buses-and-uber-partnership/

Sullivan, Bob (2015). "6 reasons Ubernomic could be fatal to itself, its customers, and mass transit". GeekWire. Retrieved from: http://www.geekwire.com/2015/6reasons-ubernomics-fatal-customers-mass-transit/

Taylor, Brian et al. (2016). "Between Public and Private Mobility: Examining the Rise of Technology-Enabled Transportation Services". Transportation Research Board; Special Report 319. Retrieved from:

http://onlinepubs.trb.org/onlinepubs/sr/sr319.pdf

Uber (2016). "Shifting expectations - Finding better ways for cities to move, work, and thrive". Uber. Retrieved from: https://www.uber.com/helping-cities/

Uber (2016). "UberSki: From the City to the Slopes!" Uber Newsroom. Retrieved from: https://newsroom.uber.com/us-utah/uberski-from-the-city-to-the-slopes/

Uber (2016). "Understanding Surge". Uber website. Retrieved from: https://help.uber.com/h/19572af0-d494-4885-a1ef-1a0d54d0e68f

United States Census Bureau (2016). American Fact Finder, demographic information by MSA, 5-year average. Retrieved from: http://factfinder.census.gov/faces/nav/jsf/pages/searchresults.xhtml?refresh=t 
Velickovic, Ivana (2015). "The Rise of Uber: Blurring the Lines of the Sharing Economy". WSP Canada. Retrieved from: http://www.wsp-pb.com/en/WSP-Canada/Who-weare/In-the-media/Blog/In-Transit/The-Rise-of-Uber-Blurring-the-lines-of-thesharing-economy/

Wadhwa, Tarun (2014). "Could Lyft and Uber Put Public Transit Out Of Business?". Forbes Tech. retrieved from:

http://www.forbes.com/sites/tarunwadhwa/2014/11/13/will-lyft-and-ubersshared-ride-service-put-public-transit-out-of-business/\#76af2eff1f58

Young, Angelo (2015). “Tesla Motors Inc. (TSLA) Has Lost \$3.5B In Value Since The Model X Debut". International Business Times. Retrieved from:

http://www.ibtimes.com/tesla-motors-inc-tsla-has-lost-35b-value-model-x-debut2135349 